\title{
Antioxidant Properties of Orally Administered of Aqueous Extracts of Selected Medicinal Plants and Paracetamol in Human Volunteers: In vivo
}

\author{
Nessrin G. Alabdallat
}

'Department of Medical Laboratory Sciences, Majmaah University, Majmaah, Saudi Arabia.

Corresponding author: Nessrin G. Alabdallat (E-mail: n.alabdallat@mu.edu.sa)

(Submitted: 19 February 2021 - Revised version received: 10 April 2021 - Accepted: 14 May 2021 - Published online: 26 June 2021)

\begin{abstract}
Objectives In the current study, we used the herbal plant extracts and studied antioxidative value against the well-known drug Paracetamol. Methods 54 Healthy volunteers were grouped into six groups, 5 groups drinking 200-250ml of aqueous extract from selected medicinal plants daily for 5 days and group six received 2 tablets of paracetamol (each tablet, $500 \mathrm{mg}$ ) daily for five days. Blood samples were taken before and $1 \mathrm{hr}$ after the administration (samples 1 and 2, respectively) and then one day after the last dose of day five (sample 3). Serum total antioxidant status (TAS), red blood cell reduced glutathione (GSH), red blood cell malonyldialdehyde (MDA), and red blood cell superoxide dismutase (SOD) were used as assays.

Results Oral administration of aqueous extracts of studied plants increased significantly the serum total antioxidant status and red blood cell reduced glutathione after 5 days of administration compared to 0 time of administration. Data also showed that red blood cell superoxide dismutase increased significantly after five days of aqueous extracts of Zingiber officinale, Rosmarinus officinalis \& Saliva triloba administration compared to 0 time of administration. Oral administration of aqueous extracts of Zingiber officinale, Rosmarinus officinalis, Verbena triphylla, caused a significant decrease in red blood cell malonyldialdehyde. Oral administration of Paracetamol for 5 days did not affect total antioxidant status red blood cell malonyldialdehyde, red blood cell reduced glutathione and red blood cell superoxide dismutase.

Conclusion Paracetamol is a very common antipyretic drug. It doesn't show antioxidative property. On other hand some herbal products (Zingiber officinale, Rosmarinus officinalis, Verbena triphylla, Saliva triloba and Origanum syriacum) having antioxidative property. Therefore, a person taking herbal product can enhance the in vivo antioxidant capacity of body by increasing the antioxidative property of body.

Keywords Antioxidants, Malondialdehyde, Glutathione, Superoxide Dismutase
\end{abstract}

\section{Introduction}

Antioxidants neutralize oxidative stress and its deleterious effects on human health. Antioxidants can stop those free radical-mediated oxidative damages due to the scavenging properties of free radicals. Because of synthetic antioxidants has toxic properties, natural antioxidants are needed. ${ }^{1,2}$

Medicinal plants are potential sources of natural antioxidants. antioxidant actions to Prevent oxidative damage are through free radical scavenging activity, inhibition of their formation due to metal chelating properties. ${ }^{3}$

Medicinal plants are widely used by people in Jordan, in fact people in Jordan taking a cup of herbal extract once or more daily as the habit of tea or coffee drinking.

Paracetamol is one of the most popular and most commonly used analgesic and antipyretic drugs around the world, available without a prescription, both in mono- and multi-component preparations.

The in vitro antioxidant properties of studied herbs previously evaluated, ${ }^{4,5}$ although there are no published studies displaying there could be in vivo antioxidants properties of the orally administrated of studied plants. Therefore, this study proposed to see the in vivo effects of the following plants: Zingiber officinale (rhizomes), Rosmarinus officinalis (leaves), Verbena triphylla (leaves), Saliva triloba (leaves), Origanum syriacum (leaves) regarding antioxidant capacities.

\section{Materials and Methods}

\section{Plant Material}

The selected plants (Zingiber officinale (rhizomes), Rosmarinus officinalis (leaves), Verbena triphylla (leaves), Saliva triloba (leaves), Origanum syriacum (leaves)) were obtained from the local herbal stores in madaba, Jordan. The choice of plant material used was dependent on the large use of public as folk medicine.

\section{Preparation of Aqueous Extracts}

250 grams of each dried plants from the following medicinal plant (Saliva triloba, Origanum syriacum, Zingiber officinale, Rosmarinus officinalis, Verbena triphylla) was poiling with 12 Liter water for 10-15 mints, and then it covered and left soaking for $4-5 \mathrm{hr}$ at $25^{\circ} \mathrm{C}$. After that the soaked or aqueous extract filled in clean bottles (each one contains $1.250 \mathrm{~L}$ ).

\section{Blood Samples}

54 Healthy volunteers were grouped into six groups, (each group $n=9$ ), their age and sex were shown in table 1.5 groups drinking 200-250 $\mathrm{ml}$ of aqueous extract from the selected medicinal plants (Saliva triloba, Origanum syriacum, Zingiber 


\begin{tabular}{lll}
\hline Table 1. Age and Sex of participant. & \\
\hline Group & Age (Mean \pm S.D.) & Female/Male \\
\hline Origanum syriacum & $35.8 \pm 14.7$ & $4 / 5$ \\
Saliva triloba & $42.8 \pm 14.6$ & $6 / 3$ \\
Verbena triphylla & $34 \pm 18.6$ & $4 / 5$ \\
Zingiber officinale & $41.8 \pm 7.6$ & $7 / 2$ \\
Rosmarinus officinalis & $35.4 \pm 13.5$ & $4 / 5$ \\
Paracetamol & $30.6 \pm 9.8$ & $3 / 6$
\end{tabular}

officinale, Rosmarinus officinalis, Verbena triphylla) daily for 5 days and group six received 2 tablets of paracetamol (each tablet, $500 \mathrm{mg}$ ) daily for 5 days.

3 blood samples were collected from each healthy volunteer (sample 1 before drinking or administration of aqueous extract), sample 2 after $1 \mathrm{hr}$ of the first dose (drinking aqueous extract) on day 1 and sample 3 next day following the last dose of day five) in gell clot activator tubes. gell tubes were centrifuged for 10 mints at $3000 \mathrm{xg}$ at $25^{\circ} \mathrm{C}$ to separate and collect serum. Then $2 \mathrm{ml}$ of distilled water added to the cells under the gell in tubes and the tubes were centrifuged for 5 mints at $3000 \mathrm{xg}$ and the supernatant was collected (hemolysate). All samples (serum and hemolysate) were stored frozen at $-20^{\circ} \mathrm{C}$ until analysis.

\section{Serum TAS Assay:}

Serum TAS measured by TAS kit from Randox. The results were expressed as Milli mole per Liter.

\section{Red Blood Cell MDA}

Red blood cell MDA was determined as a measure of lipid peroxidation according to stocks and dormandy's method ${ }^{6}$ using thiobarbituric acid (TBA) as modified by srour et al. ${ }^{7}$ All MDA concentrations were expressed as Nano mole per gram Hemoglobin.

\section{Red Blood Cell GSH}

Red blood cell GSH was determined using Ellman's method with some modification. ${ }^{8}$ All GSH concentrations were expressed in Milligram per gram Hemoglobin.

\section{Red Blood Cell SOD Activity}

Red blood cell SOD was measured using kit from Randox. The results were expressed as Unit per gram Hemoglobin.

\section{Statistical Analysis}

Data were analyzed by using SPSS (Statistical Package for Social Sciences) software, version.17.

\section{Results}

All the tested plants: Rosmarinus officinalis, Verbena triphylla, Zingiber officinale, Saliva triloba \& Origanum syriacum caused a significant increase in serum TAS at the sixth day of administration. Paracetamol did not affect serum TAS (Table 2).
All the tested plants: Zingiber officinale, Rosmarinus officinalis, Verbena triphylla, Saliva triloba, Nigella sativum \& Origanum syriacum also caused a significant increase in erythrocyte reduced glutathione at the sixth day of administration. Paracetamol did not affect erythrocyte reduced glutathione (Table 3). However, erythrocyte superoxide dismutase increased significantly at the sixth day of administration of Zingiber officinale, Rosmarinus officinalis and Saliva triloba compared to 0 time of administration, whereas Origanum syriacum \& Verbena triphylla although caused some increase in erythrocyte superoxide dismutase but did not reached to significant level (Table 4).

Oral administration of aqueous extracts of Zingiber officinale, Verbena triphylla, Rosmarinus officinalis caused a significant decrease in erythrocyte Malonyldialdehyde (MDA) at the sixth of administration. Paracetamol did not affect erythrocyte MDA (Table 5).

\begin{tabular}{|c|c|c|c|}
\hline \multicolumn{4}{|c|}{ TAS (mmol/l) } \\
\hline & 0 time & $1 \mathrm{hr}$ (day 1) & Day 6 \\
\hline Rosmarinus officinalis & $1.14 \pm 0.3$ & $1.31 \pm 0.27^{*}$ & $1.30 \pm 0.20^{*}$ \\
\hline Verbena triphylla & $1.23 \pm 0.2$ & $1.36 \pm 0.2^{*}$ & $1.37 \pm 0.22^{*}$ \\
\hline Zingiber officinale & $1.08 \pm 0.16$ & $1.20 \pm 0.10$ & $1.24 \pm 0.12^{*}$ \\
\hline Saliva triloba & $1.12 \pm 0.11$ & $1.16 \pm 0.15$ & $1.22 \pm 0.16^{*}$ \\
\hline Origanum syriacum & $1.14 \pm 0.10$ & $1.21 \pm 0.11$ & $1.28 \pm 0.09^{*}$ \\
\hline Paracetamol & $1.4 \pm 0.27$ & $1.36 \pm 0.3$ & $1.31 \pm 0.9$ \\
\hline
\end{tabular}

Table 3. Reduced glutathione (GSH) $\mathbf{m g} / \mathbf{g ~ H b}$ of the given medicinal plants. Each value represents the mean \pm S. D., $(n=9)$, *P value $\leq 0.05$, compared to the 0 time administration.

\begin{tabular}{lll}
\hline & GSH & \\
\hline & $\mathbf{0}$ time & Day 6 \\
Zingiber officinale & $0.74 \pm 0.31$ & $1.53 \pm 0.37^{*}$ \\
Rosmarinus officinalis & $0.82 \pm 0.13$ & $1.41 \pm 0.23^{*}$ \\
Verbena triphylla & $0.80 \pm 0.15$ & $1.05 \pm 0.14^{*}$ \\
Saliva triloba & $0.54 \pm 0.09$ & $0.87 \pm 0.10^{*}$ \\
Origanum syriacum & $0.73 \pm 0.11$ & $0.80 \pm 0.10^{*}$ \\
Paracetamol & $0.73 \pm 0.12$ & $0.75 \pm 0.13$ \\
\hline
\end{tabular}

Table 4. Superoxide dismutas (SOD) $\mathbf{U} / \mathbf{g H b}$ of the given medicinal plants. Each value represents the mean \pm S.D., $(n=8)$, *P value $\leq 0.05$, compared to the 0 time administration

\begin{tabular}{lll}
\hline & GSH & \\
\hline & $\mathbf{0}$ time & Day 6 \\
Zingiber officinale & $1005.4 \pm 298.0$ & $1374.5 \pm 160.1^{*}$ \\
Rosmarinus officinalis & $1106.6 \pm 118.3$ & $1340.5 \pm 134.0^{*}$ \\
Saliva triloba & $868.0 \pm 167.1$ & $997.5 \pm 192.4^{*}$ \\
Verbena triphylla & $1132.0 \pm 139.0$ & $1210.3 \pm 119.2$ \\
Origanum syriacum & $1037.1 \pm 155.3$ & $1098.0 \pm 181.5$ \\
Paracetamol & $1114.5 \pm 256.6$ & $1091.2 \pm 172.1$ \\
\hline
\end{tabular}




\begin{tabular}{lcc}
$\begin{array}{l}\text { Table 5. Malonyldialdehyde (MDA) } \mathbf{n m o l} / / \mathbf{g} \mathbf{H b} \text { of the given } \\
\text { medicinal plants. Each value represents the mean } \mathbf{\pm} \text { S. } \mathbf{D} . \mathbf{}(\mathbf{n}=\mathbf{9}) \text {. }\end{array}$ \\
\hline \multicolumn{3}{c}{ MDA } \\
\hline Zingiber officinale & $\mathbf{0}$ time & Day $\mathbf{6}$ \\
Verbena triphylla & $22.9 \pm 4.5$ & $16.2 \pm 3.7^{*}$ \\
Rosmarinus officinalis & $27.7 \pm 4.8$ & $22.9 \pm 3.4^{*}$ \\
Saliva triloba & $21.2 \pm 2.0$ & $17.7 \pm 2.8^{*}$ \\
Origanum syriacum & $17.9 \pm 3.4$ & $15.8 \pm 3.8$ \\
Paracetamol & $17.5 \pm 3.4$ & $16.4 \pm 3.5$ \\
\hline
\end{tabular}

\section{Discussion}

Oral administration of aqueous extracts of Zingiber officinale, Rosmarinus officinalis, Verbena triphylla, Saliva triloba, Origanum syriacum increased significantly the serum TAS after 5 days of administration. This result coincides with the findings of other researchers ${ }^{9,10}$ who have showed that the total plasma antioxidant capacity increased in diabetic rats treated with Nigella sativa crude extract. The present study also showed that all studied plants caused a significant increase in erythrocyte reduced glutathione after five days of administration. This result coincides with the findings of other researchers ${ }^{9,11-16}$ who have showed that oral administration of extracts of Zingiber officinale or Nigella sativum increased significantly reduced glutathione or antioxidant status in the liver \& kidney tissues of mice \& rats. The present study also showed that erythrocyte superoxide dismutase (SOD) increased significantly at the sixth day of Zingiber officinale, Rosmarinus officinalis \& Saliva triloba administration. This result coincides with the findings of other researchers ${ }^{11,17,18}$ who have showed that oral administration of extracts of Rosmarinus officinalis or Zingiber officinale increased significantly the activity of superoxide dismutase (SOD) in the liver of mice or in serum of diabetic rabbits. The present study also showed that Oral administration of aqueous extracts of Zingiber officinale, Rosmarinus officinalis, Verbena triphylla, caused a significant decrease in erythrocyte Malonyldialdehyde (MDA) after five days of administration. This result coincides with the findings of other researchers ${ }^{13,17}$ who have showed that oral administration of extracts of Nigella sativum or Rosmarinus officinalis decreased significantly MDA in the liver of mice \& in serum of diabetic rabbits.
The most likely explanation for the increased serum total antioxidant capacity would therefore be as a result of the intestinal absorption with consequent accumulation of the antioxidant compounds contained in the administered plant extracts. The serum concentration of the absorbed antioxidant compounds could also be dependent on their renal clearance which supposed to be dependent on the hydration state of the body \& varied according to the chemical structure from one compound to another. This could explain the variation between the tested plants in regard to the time taken after the dose in increasing serum total antioxidant capacity (Table. 2). The increased erythrocyte content of reduced glutathione \& activity of superoxide dismutase \& the decreased erythrocyte content of MDA indicate the improved cellular antioxidant capacity of the body resulted from the administration of tested plant extracts. However, the present study could not tell the mechanism by which the tested plants increased cellular reduced glutathione \& activity of superoxide dismutase \& decreased cellular MDA. To our knowledge the present study is the first ever in vivo study in humans regarding the antioxidant properties of tested plants.

\section{Ethical Approval and Consent to Participate.}

This study was approved by the committee of the University of Jordan, and have therefore been performed in accordance with the ethical standards laid down in the $1964 \mathrm{dec}-$ laration of Helsinki. Informed consent was obtained from each individual participants prior to their participation in the research.

\section{Competing Interests}

Author has declared that there are no conflicts of interest.

\section{Funding}

This study was funded by the deanship of scientific research, Majmaah University, Research Project Number (R-2021-143).

\section{Acknowledgments}

The author would like to thank Deanship of Scientific Research at Majmaah University for supporting this work under Project Number R-2021-143.

\section{References}

1. Valko, M. Rhodes, C. Moncol, J. Izakovic, M. Mazur, M. Free radicals, metals and antioxidants in oxidative stress-induced cancer. Chem. Biol. Interact. 2006;160:1 -40

2. Valko, M. Leibfritz, D. Moncol, J. Cronin, M.T. Mazur, M. Telser, J. Free radicals and antioxidants in normal physiological functions and human disease. Int. J. Biochem. Cell Biol. 2007;39:44 -48.

3. Soobrattee, M. Neergheen, V. Luximon-Ramma, A. Aruoma, O. Bahorun, T. 2005. Phenolics as potential antioxidant therapeutic agents: Mechanism and actions. Mutat. Res. Fundam. Mol. Mech. Mutag. 2005;579:200 -213.

4. Bilto Y. Y., Alabdallat N. G. In vitro and in vivo antioxidant related effects of rosemary (Rosmarinus Officinalis L.) extracts in humans. American Journal of Clinical and Experimental Medicine. 2015;3:213-221.

5. Bilto Y.Y., Alabdallat N. G. and Maher Salim: Antioxidant properties of twelve selected medicinal plants commonly used in Jordan. British Journal of Pharmaceutical Research. 2015;6:121 -130.

6. Stocks, J, and Dormandy, T. L. The autoxidation of human red cell lipids induced by hydrogen peroxide. British Journal of Hematology. 1971;20:95 $-111$.

7. Srour, M. A. Bilto, Y. Y. Juma, M. Irhimeh, M. R. Exposure of human erythrocytes to oxygen radicals causes loss of deformability, increased osmotic fragility, lipid peroxidation and protein degradation. Clinical Hemorheology and Microcirculation. 2000;23:13 -21.

8. Ellman, G. L. Tissue Sulfhydryl (-SH) Groups. Archive of Biochemistry and Biophysiology. 1951;82:70 -77. 
9. Bilto Y. Y., Alabdallat N. G. Ex vivo and in vivo Antioxidant related effects of zingiber officinale roscoe (Ginger) extracts in humans. European Journal of Medicinal Plants. 2015;7:99-108

10. Houcher Z. et al. Effects of methanolic extract of nigella sativa $L$. in alloxaninduced diabetic rats. Pteridines. 2007;18:8-18

11. Asnani and Verma (2009)

12. Kaleem M, Kirmani D, Asif M, Ahmed Q \& Bano Bilqees. Biochemical effects of Nigella sativa $L$ seed in diabetic rats. Indian Journal of Experimental Biology. 2006;44:745 -748

13. El shenawy et al. (2018)

14. Ali BH. The effect of Nigella sativa oil on gentamicin nephrotoxicity in rats. Am J Chin Med. 2004;32:49-55.

15. Khan N, Sharma S, Sultana S. Nigella sativa (black cumin) ameliorates potassium bromate-induced early events of carcinogenesis: diminution of oxidative stress. Hum Exp Toxicol. 2003;22:193 -203

16. El-Dakhakhny M, Barakat M, El-Halim MA, Aly SM. Effects of Nigella sativa oil on gastric secretion and ethanol induced ulcer in rats. J Ethnopharmacol. 2000:72:299-304.
17. Bakirel et al. (2008)

18. Ajith TA, Hema U, Aswathy MS. Zingiber officinale Roscoe prevents acetaminophen-induced acute hepatotoxicity by enhancing hepatic antioxidant status. Food and Chemical Toxicology. 2007:45: 2267 -2272 .

19. Veena A, and Ramtej V. Ameliorative effects of ginger extract on paraben-induced lipid peroxidation in the liver of mice. Acta Poloniae Pharmaceutica-Drug Research. 2009;66:225 -228.

20. Tülay B, Utku B, Oya U. K, Sinem G, Ulgen, Hasret Y. In vivo assessment of antidiabetic and antioxidant activities of rosemary (Rosmarinus officinalis) in alloxan-diabetic rabbits. J Ethnopharmacol. 2008;116:64 $-73$

21. Nahla EL-S, Maha S, \& Shimaa R. The effect of antioxidant properties of aqueous garlic extract and Nigella sativa as anti-schistosomiasis agents in mice. Rev. Inst. Med. trop. S. Paulo.2008:50:29-36.

22. Ohkawa H, Ohishi N, Yagi K. Assay for lipid peroxides in animal tissues by thiobarbituric acid reaction. Anal Biochem. 1979;95:351 -358.

This work is licensed under a Creative Commons Attribution-NonCommercial 3.0 Unported License which allows users to read, copy, distribute and make derivative works for non-commercial purposes from the material, as long as the author of the original work is cited properly. 